\title{
プレストレストコンクリート圧着柱の曲げ耐力評価 FLEXURAL CAPACITY EVALUATION OF PRECAST PRESTRESSED CONCRETE COLUMNS
}

\author{
西山峰広*, 谷昌 典** \\ Minehiro NISHIYAMA and Masanori TANI
}

\begin{abstract}
A flexural capacity evaluation method for precast prestressed concrete columns is proposed in the paper based on cyclic loading tests on post-tensioned column-foundation assemblages by the authors and several column specimens in past research. The ACI rectangular concrete stress block and the design equations in Standard for Structural Design and Construction of Prestressed Concrete Structures published by Architectural Institute of Japan are also used for comparison. The proposed evaluation method for flexural capacity of precast prestressed concrete columns is verified against the experimental results. A good agreement is obtained between the evaluated and experimental results. Precast columns post-tensioned by unbonded tendons are included taking incompatibility of strains between concrete and prestressing steel into account.
\end{abstract}

Keywords: Prestressed concrete, column, post-tensioned, prestress, bond, flexural capacity, unbond プレストレストコンクリート, 柱, ポストテンション, プレストレス, 付着, 曲け耐カ, アンボンド

1.はじめに

プレストレストコンクリート（以下 PC と略記）は, 圧着工法とし て構造骨組に利用されてきており，すでにプレキャスト PC（以下 PCaPC と略記）を利用した超高層建物も建設されている。プレスト レスは元来, たわみを制御したり，ひび割れの発生を抑制したり，大 スパンを可能にするなど常時荷重下での部材性能を向上させるため に導入される。一方, PCaPC では, 施工性の観点から柱にもプレス トレスを導入する。この場合, 柱軸圧縮力に加えて, プレストレスカ を与えることになるので, 柱は大きな玫縮力を受けることになる。通 常は，長期軸力とプレストレスカをあわせた軸圧縮力が，長期許容圧 縮応力度以内となるように柱断面を大きくしたり,コンクリート設計 基準強度を上げたりすることになる。このような大きな軸圧樎力は， 一般に柱の変形性能にとっては不利となるが, 過大とならない限りは, プレストレスによる復元性に期待することができる。すなわち，地震 後の残留変形を小さくすることが可能となる。

PC 柱の研究は，過去いくつか見られるが，設計に必要となる曲げ 耐力, せん断耐力, 变形性能などに関しての知見が十分に得られてい るとは言えない。曲げ耐力に関して言えば, 柱の場合, 特に軸力が大 きく，鋼材が降伏しない場合, コンクリートの耐荷性状の影響もあり， その曲け耐力の評価は難しいものとなっている。特に圧縮側に配置さ れた鋼材の扱いが重要となる。

\footnotetext{
$*$ 京都大学大学院工学研究科都市環境工学専攻 助教授・工博

** 京都大学大学院工学研究科都市環境工学専攻 大学院生·工修

さらには, まもなく公示される PCに関する改正告示では, アンボ ンド PC 鋼材を構造部材に利用できるようになる。アンボンド PC 部 材は, グラウト注入の手間がないことに加え, 再緊張を行えること, および, 脱着可能な接合部とすることができることなどにより, 圜境 対応型の構造を構策できることが最近注目されている。また, アンボ ンドとすることにより, 骨組の大変形時においても PC 鋼材を弾性範 囲に保持することが可能となり, 復元性を高めることができる。この ような骨組とエネルギー吸収デバイスなどとを組み合わせて, 新しい 構造システムを構築することも可能である。

過去, 梁部材に対しては, アンボンド PCに関する実験的および解 析的研究が行われてきた。付着がないため, 平面保持仮定が成立せず,

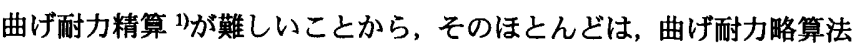
を提案するものであった 2),3)。略算法では, 曲け耐力時の PC 鋼材応 力を簡単な式で表現するものであり,これと, コンクリートの応力ー ひずみ関係を用いて曲げ耐力を算定する。あるいは，曲け耐力自体を 略算式で与える提案もある。一方, アンボンド PC 柱に対する研究は ない。

本研究では，PC 圧着柱の曲げ酎力評価方法に関して検討する。付 着のある場合とない場合のプレキャスト PC柱に対する載荷実験結果 に基づき, ACI 応カブロックを用いた平面保持解析, 日本建築学会「プ レストレストコンクリート設計施工規準・同解説」に記されている略 
算式などに対して検討を加え, 最終的に PC 柱の曲げ耐力算定法を提 案する。

ここで対象としているのは PCaPC 柱であるが, 特に圧着部あるい は压着部グラウトモルタルに関して扱ってはいない。PCa としている のは, 柱と基礎部の接合面では PC 鋼材のみが通し配筋されている場 合を扱っているためである。

\section{2. 曲げ预力の平価}

\section{1 鋼材の付稀}

付着のない鋼材を用いた PC 部材の曲け耐力評価に関しては, 過去, いくつかの研究が発表されているが, その対象は, 軸力が作用しない 梁部材である。また，ACI 規準で想定しているように，鈶直荷重下で の挙動を扱ったものが多く，地震時荷重を想定した研究はほとんどな い。

付着のない鋼材を用いた PC 部材の曲け耐力時 PC 鋼材張力は, 部 材の変形状態によって决定される。これは，鐭材の全長にわたる伸び と, 鋼材配膡位固でのコンクリートひずみの皘分値として得られるコ ンクリートの伸びが等しいという変形適合条件が満足されるためで ある。このような条件を満足するような数值解析を行うことは可能で あり，また，有限要素法も適用できるので，いくつかの研究が発表さ れている 4).5)。しかしながら，そのような解析は煩雑であり，設計実 務には向かないものとなる。そのため, 简略で精度のよい曲け耐力評 価法が望まれる。そのひとつとしてモーメントが最大となる断面にお いて, コンクリートのひずみ增分に対する龬材のひずみ增分の比を $\mathrm{F}$ 值として定義し，これを載荷状態や断面配飭などをパラメータに与え ることにより鋼材の応力を决定し, コンクリートに対しては平面保持 を仮定した断面解析を行うことが略算法として提案されている

\section{2 圧樎側鋼材の考虑}

文献 7)では，PC 鋼材が多段配度された断面の終局曲げ強度を算定 する際に圧維側に位固するPC銅材の引張力を一定值の仮想軸力とし て算定式に考慮する式（以下，A 式とする）を提案している。また， 文献 8)では, 上記の学会式に軸力項を付加し, 軸力を受ける柱部材 にも対応できる形で曲け耐力算定式を示している。しかしながら，文 献 7),8)共に, 軸力を受けない梁部材に関する検封のみで, 軸力を受 ける部材に関する検討はなされていない。そこで，本論文では，A 式 を柱部材に適用する場合の耐力算出過程に関して検討を行い, 必要に 応じて修正を加え，過去に行われた実験結果と比較検討する。

梁部材を対象とした A 式では, PC 鋼材の圧縮側判定用に用いる $x_{n}$ の第一次近似值算出時に，全 PC 鋼材が降伏していると仮定して $q_{\text {total }}$ を用いているが，本論文で提案する柱部材を対象とした方法（以下， B 法とする) では， $x_{n}$ の第一次近似值算出には，PC 鋼材張力を有効 プレストレスカとした $q_{e}$ を用いるものとする(理由については後述)。 なお， $q_{e}$ には軸力の項も含まれている。計算の流れを以下に示す。 (1) $q_{e}$ を用いて $x_{n}$ の第一次近似值を算出し, PC 鋼材の圧縮側判定を行 う。

$$
\begin{aligned}
& q_{e}=\left(P_{e}-a_{c} \sigma_{y}+N\right) / b D F_{c} \\
& x_{n}=\left(q_{e} / k_{1} k_{3}\right) D
\end{aligned}
$$

(2) 圧縮側と判定された PC 鋼材の張力は A 式に示される仮想軸力の 式を用いて算出し, 引張側と判定された PC 鋼材張力は降伏耐力と する。

$$
\begin{aligned}
& \zeta_{i}=0.25+0.6 d_{c p 1 i} / q_{\text {total }}{ }^{\prime} \\
& q_{\text {total }}{ }^{\prime}=\left(a_{p g} \sigma_{p y}-a_{c} \sigma_{y}+N\right) / b D F_{c}
\end{aligned}
$$

(3) 圧縮鉄筋の降伏を仮定して, 力の釣合からコンクリート合力 $C c$ を求め $x_{n}$ を再計算する。なお, 普通引張鉄笳は通し配筋されてい ないため引張力を負担しないとして無視する。

$$
\begin{aligned}
C_{c} & =a_{p} \sigma_{p y}-a_{c} \sigma_{y}+N+\sum \zeta_{i} P_{e i} \\
x_{n} & =C_{c} /\left(k_{1} k_{3} b F_{c}\right) \\
& =\left(a_{p} \sigma_{p y}-a_{c} \sigma_{y}+N+\sum \zeta_{i} P_{e i}\right) /\left(k_{1} k_{3} b F_{c}\right)
\end{aligned}
$$

(4) 断面内の応力分布が決定するので，モーメントを求める。

$$
M_{u}=a_{p} \sigma_{p y} d_{p}-a_{c} \sigma_{y} d_{c}-C_{c} k_{2} x_{n}+\sum \zeta_{i} P_{e i} d_{c p i}+N D / 2
$$

ここで

$a_{p} a_{c} ：$ 引張側 PC 銅材及び圧縮鉄筋の断面積

$b, D:$ 梁幅及び梁せい

$d_{p} d_{c}$ : 引張側 PC 鋼材及び圧維鉄筋の重心位圈から梁断面の圧縮 悢までの距離

$\sigma_{p y}, \sigma_{y}: \mathrm{PC}$ 銚材及び圧縮鉄筋の降伏強度

$F_{c}$ : コンクリート設計基準強度

$P_{e}: \mathrm{PC}$ 釗の有効プレストレスカ

$k_{1}, k_{2}, k_{3}$ ：曲げ圧雉部コンクリートの応カブロック係数 $\left(k_{1} k_{3}=0.83, k_{2}=0.42\right.$ とする)

$a_{P g}$ : 断面に配㯰された $\mathrm{PC}$ 鋼材断面積の総和

$d_{c p}$ : 圧縮側にある PC 鋼材の重心位直から圧縮縁までの距離 $d_{c p t}=d_{c p} / D$

後に図 6 に示すように，曲け耐力時の鋼材張力の合計值は, 有効プ レストレスカと大きく違わないが, 銅材の配置状態や断面に作用する 軸力やプレストレスカの大きさによっては，(2)式と(6)式による $x_{n}$ が 異なることもある。そのような場合でも，曲げ耐力自体への影響はさ ほど大きくない。

なお，付着のない場合の PC 鋼材張力增分については，付着のある 場合の有効プレストレスカからの PC 鋼材張力増分に 0.2 を乗じたも のとする。これは，逆対称曲げを受けるアンボンド PC 梁部材に対す る研究 6)においてひずみの適合保数 $\mathrm{F}$ 值を 0.2 とすればよい精度で曲 け耐力を評価できることに対応する。

\section{3. 実験による検討}

\section{1 実験概要}

試験体は，表 1 に示す 2 シリーズ計 10 体である。実験パラメータ は, グラウトの有無と柱軸力比である。試験体作製に使用した材料の 力学特性を表 2 と表 3 に示す。なお, 鉄筋応力を求める際には, 公称 断面積を用いた。試験体名に PCa が付く A シリーズは，すでに文献 9)において，また，u1，u2，b1 および b2 の 4 体の B シリーズに関し 
表 1 試験体一覧

\begin{tabular}{|c||c|c|c|c|}
\hline 試験体名 & $\begin{array}{c}\text { グラウトの } \\
\text { 有無 }\end{array}$ & $\eta_{N}$ & $P_{e}(\mathrm{kN})$ & $\eta_{N+P}$ \\
\hline \hline$P C a-u 1$ & 無 & 0.15 & 603.4 & 0.430 \\
\hline$P C a-u 2$ & 無 & 0.30 & 609.7 & 0.583 \\
\hline$P C a-u 3$ & 無 & 変動軸力 & 606.2 & $0.281^{*}$ \\
\hline$P C a-b 1$ & 有 & 0.15 & 618.5 & 0.437 \\
\hline$P C a-b 2$ & 有 & 0.30 & 610.5 & 0.583 \\
\hline$P C a-b 3$ & 有 & 変動軸力 & 628.7 & $0.292^{*}$ \\
\hline \hline$u 1$ & 無 & 0.10 & 664.0 & 0.406 \\
\hline$u 2$ & 無 & 0.20 & 677.6 & 0.521 \\
\hline$b 1$ & 有 & 0.10 & 636.0 & 0.393 \\
\hline$b 2$ & 有 & 0.20 & 694.4 & 0.520 \\
\hline
\end{tabular}

$\eta_{N}=N /\left(A_{c} \cdot f_{c}^{\prime}\right), \quad \eta_{N+P}=\left(N+P_{c}\right) /\left(A_{c} \cdot f_{c}^{\prime}\right) \quad N$ : 軸力, $P_{e}:$ 軸力載荷直 前のプレストレスカ, $A_{c}$ : 柱断面積, $f_{c}^{\prime}$ : コンクリート圧縮強度, ${ }^{*} P_{e}$ のみ考慮

ては文献 10)で発表している。ここでは，B シリーズについてのみ実 験概要を简単に示す。A シリーズと B シリーズの試験体形状・配筋 などはほぼ同じである。

図 1 に試験体とその配筋詳細を示す。柱部分と基礎部分を別々に打 設した後， $15 \mathrm{~mm}$ 厚の高強度無収縮モルタルを介して両者を接合し， プレストレスを導入した。試験对象部分である柱の破壊時においても 基礎部分には曲げとせん断に対する補強筋を配圈するとともに, 大き な損傷が生じないように，横方向にプレストレスを導入した。載荷は， $2000 \mathrm{kN}$ ジャッキで定軸力を与えながら $1000 \mathrm{kN}$ ジャッキで水平力を 加えた。

柱コンクリート断面を決めた後, $\mathrm{PC}$ 鋼材の許容引張応力度 $0.8 \sigma_{p y}$ （ $\sigma_{p y}: \mathrm{PC}$ 鋼材の規格降伏応力度）まで最大限利用した時に柱コンク リート断面に対するプレストレスカによる圧縮応力が $1 / 3 f^{\prime}{ }^{\prime}$ 程度とな るように PC 鋼材断面栍を決定した。通常は, 長期軸力とプレストレ スカを合わせた柱軸力が $1 / 3 f^{\prime}$ c となるように設計されるが, 本実験で は, 軸力のない梁との違いを明確にするため, 大きめの軸力とプレス トレスカを設定した。これは外柱の軸力増加側を想定していることに もなる。

図 2 にグラウトを行った A シリーズ試験体 PCa-b1, PCa-b2 および B シリーズ試験体 $b 1, b 2$ の N-M インターアクション曲線を示す。図 2 では圧縮を正としている。ここで，曲け耐力の計算には， $\mathrm{ACI}$ のコンクリート态カブロックと PC鋼材材料強度を使用し た。また,コンクリート強度には, 目地部モルタルの圧縮強 度を用いずに，柱母材のコンクリート強度を用いた。また， せん断補強筋の 4 隅に配置されているD10 の組み立て筋は， 圧縮にのみ有勃であるとした。これらの試験体にはプレスト レスカが導入されているため, N-M インターアクション曲線 が RC 柱に対するものと比べて, 引張側にシフトしたような形 となっている。各試験体のモーメントと軸力の組み合わせは 図中に示されている。設定した軸力は, 釣合軸力以上となっ ていることが分かる。B シリーズ試験体 b1 と b2 では，有効 プレストレスカの大きさが多少異なるため, N-M 関係にも少
表 2 鉄筋と PC 鋼材の力学特性

\begin{tabular}{|c||c|c|c|}
\hline 鋼材種 & $\begin{array}{c}f_{y} \\
\left(\mathrm{~N} / \mathrm{mm}^{2}\right)\end{array}$ & $\begin{array}{c}f_{u} \\
\left(\mathrm{~N} / \mathrm{mm}^{2}\right)\end{array}$ & $\begin{array}{c}E_{s} \\
\left(\times 10^{5} \mathrm{~N} / \mathrm{mm}^{2}\right)\end{array}$ \\
\hline \hline $\mathrm{D} 19(\mathrm{SD} 345)$ & 390 & 607 & 1.68 \\
\hline $\mathrm{D} 10^{* 1}(\mathrm{SD} 295)$ & 325 & 475 & 1.54 \\
\hline $\mathrm{D} 10^{* 1}(\mathrm{SDR} 295)$ & 317 & 441 & 1.58 \\
\hline \hline$\phi 17$ & $1053^{* 2}$ & 1123 & $2.00^{* 3}$ \\
\hline$\phi 23$ & $1032^{* 2}$ & 1135 & $2.00^{* 3}$ \\
\hline
\end{tabular}

$f_{y}$ : 降伏強度, $f_{u}$ : 引張強度, $E_{s}:$ ヤング倸数

*1: D10SD295 は, 柱せん断補強筋として, D10 SDR295 は, 基礎部 せん断補強筋として利用

*2: 0.2\%オフセット降伏応力, *3: 規格值

表 3 コンクリートとグラウトの力学特性

\begin{tabular}{|c||c|c|c|}
\hline & $\begin{array}{c}f^{\prime}{ }^{\prime} \\
\left(\mathrm{N} / \mathrm{mm}^{2}\right)\end{array}$ & $\begin{array}{c}\varepsilon_{\mathrm{cm}} \\
(\%)\end{array}$ & $\begin{array}{c}E_{c} \\
\left(\mathrm{x} 10^{4} \mathrm{~N} / \mathrm{mm}^{2}\right)\end{array}$ \\
\hline 試験体 & 39.5 & 0.224 & 2.53 \\
\hline $\mathrm{PC}$ 鋼材グラウト & 33.7 & 0.251 & 1.32 \\
\hline 接合目地グラウト & 43.8 & 0.331 & 1.8 \\
\hline
\end{tabular}

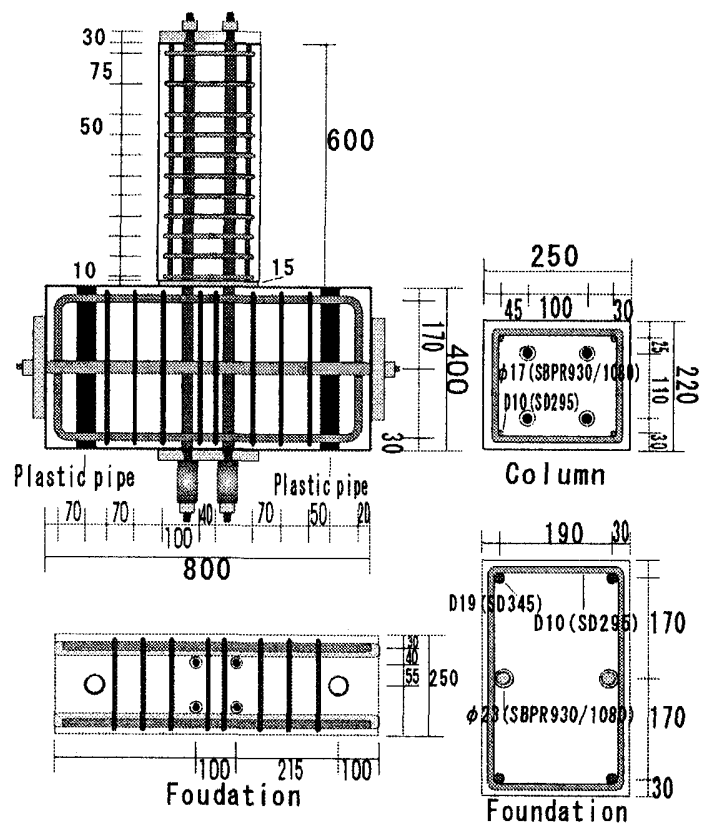

図 1 試験体と配筋詳細

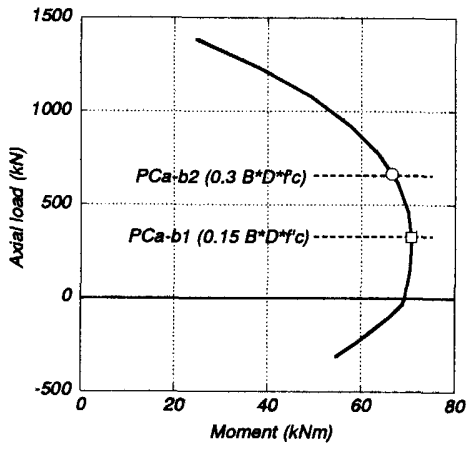

(a)A シリーズ試験体

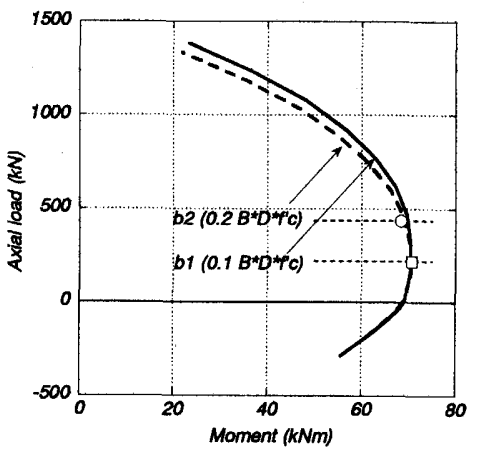

(b)B シリーズ試験体
図 2 N-Mインターアクションカーブ 
し差が生じている。

\section{2 実験結果}

試験体はすべて柱脚部で曲げ圧縮破壊した。A シリ 一ズでは, 低軸力と変動軸力を受ける $P C a-b 1, b 3, u 1$ お よび $u 3$ に対して，7.5\%の部材角まで載荷し，高軸力を 受ける $P C a-b 2$ と $u 2$ には, $5.0 \%$ まで載荷した。一方, B シリーズにおいては, 低軸力を受ける $b 1, u 1$ および高 軸力を受ける $b 2$ では, $\pm 7.5 \%$ 最終載荷変位まで達し， 高軸力を受ける付着のない試験体 $u 2$ では, 最終載荷変 位に達する以前に軸力を支持できなくなったため，士 $5.0 \%$ で載荷を終了した。

図 3 に各試験体の柱脚部モーメント一柱部材回転角 関係を示す。モーメントには軸力による付加モーメン トも加えてある。高軸力を受ける $b 2$ とu2 では, $b 1$ と $u 1$ に比べて, 最大耐力到達以後の耐力低下が大きくな っている。

\section{3 酎力算定式と実験結果の比較}

本実験のような片持ち柱は, 基礎部における銅材伸びを考慮する必 要があるが, 中央集中荷重を受ける単純梁の半分とほぼ同様な変形状 態と考えられる。柱の場合，PC 鋼材は，実際には，数層にわたって 配置されることになる。したがって，本実験のような片持ち柱形式の 載荷では，PC 鋼材の伸びは，実際と比べて大きくなっていると考え られる。文献 2)によると, このような単純梁の PC 鋼材張力增分は変 形適合俰数 $F$ 值で表現すると 0.2 程度となる。そこで, $\mathrm{ACI}$ のコンク リート応カブロックと, 付着のある試験体に対しては平面保持の仮定 を用いて，付着の無い試験体についてはこの $F$ 值 0.2 を適用して，そ れぞれ曲げ耐力を算出する。結果を表 4 の $M_{A C I}$ として示す。この計 算結果と実験結果の比較からは，実験值が計算值を 6 78\%上回る。 PC 鋼材に対して平面保持を仮定した解析結果でも付着のない試験体 の曲げ耐力より小さくなっている。なお, 実験から得られた正負の曲 げ耐力が異なっている試験体もある。これは，軸力の作用により，原 点においてもモーメントが作用した状態となっているためと考えら れる。

また，提案 B 法を用いて算定した曲け耐力を $M_{p r o p}$ として表 4 に併 せて示す。平面保持仮定を用いて算出した $M_{A C I}$ と比べて全体的に耐 力を大きく評価しており, 実験結果に近い耐力を算出できていること が分かる。また, 軸力の低い試験体の曲げ耐力よりも軸力の高い試験 体の曲げ耐力の方が大きくなっており，実験結果の傾向と一致する。

一般に高軸力を受ける柱の場合, コンクリートのモデル化の影響が 大きくなり，計算の結果得られる曲け耐力は，実験值よりも小さくな る傾向にある。後の PC 鋼材ひずみの検討でも示されるが，実験時の PC 銅材ひずみは，降伏にまで達していない。また，付着のある試験 体においても，実験値が計算値を 6〜56\%上回ることからもわかるよ うに, 釣合軸力を超えるような高い軸力を受ける柱部材の曲け耐力評 価は過小評価になる傾向がある。これは, Ang らによる研究 ${ }^{11) に よ っ ~}$ ても指摘されている。さらには, $\mathrm{ACI}$ のコンクリート応カブロックに
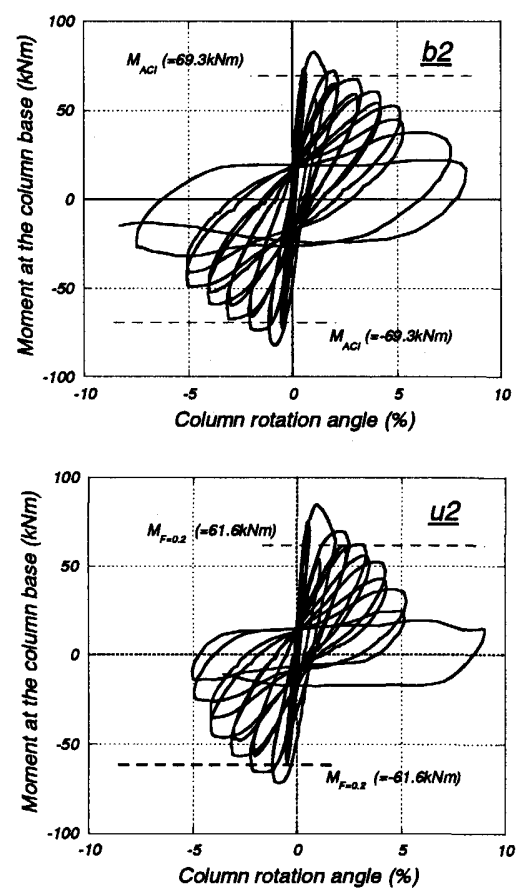

図 3 柱脚部モーメントー柱部材角関倸

表 4 曲け耐力実験値と計算値

\begin{tabular}{|c|c|c|c|c|c|c|}
\hline 試験体 & $\begin{array}{c}M_{\text {exp }} \\
(\mathrm{kNm})\end{array}$ & $\begin{array}{l}M_{\text {ev }}{ }^{7} \\
(\mathrm{kNm})\end{array}$ & $\begin{array}{c}M_{A C t} \\
(\mathrm{kNm})\end{array}$ & $M_{\exp } / M_{A C I}$ & $\begin{array}{c}M_{\text {prop }} \\
(\mathbf{k N ~ m})\end{array}$ & $M_{\text {exp }} / M_{\text {prop }}$ \\
\hline \multirow{2}{*}{$P C a-u 1$} & 82.3 & \multirow{2}{*}{83.8} & \multirow{2}{*}{63.8} & 1.29 & \multirow{2}{*}{73.3} & 1.12 \\
\hline & -85.2 & & & 1.34 & & 1.16 \\
\hline \multirow{2}{*}{$P C a-u 2$} & 87.3 & \multirow{2}{*}{96.2} & \multirow{2}{*}{59.0} & 1.48 & \multirow{2}{*}{73.9} & 1.18 \\
\hline & -105.1 & & & 1.78 & & 1.42 \\
\hline$P C a-u 3$ & 74.4 & - & $\begin{array}{c}57.5 \\
(691.1)^{\circ 2}\end{array}$ & 1.29 & 73.3 & 1.02 \\
\hline \multirow{2}{*}{$P C a-b 1$} & 86.5 & \multirow{2}{*}{88.1} & \multirow{2}{*}{70.9} & 1.22 & \multirow{2}{*}{86.4} & 1.00 \\
\hline & -89.7 & & & 1.27 & & 1.04 \\
\hline \multirow{2}{*}{$P C a-b 2$} & 89.4 & \multirow{2}{*}{97.4} & \multirow{2}{*}{67.4} & 1.33 & \multirow{2}{*}{86.8} & 1.03 \\
\hline & -105.3 & & & 1.56 & & 1.21 \\
\hline \multirow{2}{*}{$P C a-b 3$} & 92.5 & - & $\begin{array}{c}63.1 \\
(778.9)\end{array}$ & 1.47 & 76.6 & 1.21 \\
\hline & -73.2 & - & $\begin{array}{c}-69.3 \\
(-25.2)\end{array}$ & 1.06 & 70.1 & 1.04 \\
\hline \multirow{2}{*}{$u 1$} & 72.8 & \multirow{2}{*}{75.8} & \multirow{2}{*}{63.3} & 1.15 & \multirow{2}{*}{71.4} & 1.02 \\
\hline & -78.7 & & & 1.24 & & 1.10 \\
\hline \multirow{2}{*}{$u 2$} & 84.9 & \multirow{2}{*}{78.4} & \multirow{2}{*}{62.7} & 1.35 & \multirow{2}{*}{74.9} & 1.13 \\
\hline & -71.9 & & & 1.15 & & 0.96 \\
\hline \multirow{2}{*}{$b 1$} & 84.7 & \multirow{2}{*}{83.1} & \multirow{2}{*}{70.6} & 1.20 & \multirow{2}{*}{83.0} & 1.02 \\
\hline & -81.5 & & & 1.15 & & 0.98 \\
\hline \multirow{2}{*}{$b 2$} & 82.8 & \multirow{2}{*}{82.3} & \multirow{2}{*}{69.3} & 1.19 & \multirow{2}{*}{86.4} & 0.96 \\
\hline & -82.3 & & & 1.19 & & 0.95 \\
\hline
\end{tabular}

*1 $M_{a v}(\mathrm{kNm})$ : 正方向載荷時と負方向載荷時の平均值, ただし, 変動軸力を受ける試験体 $P C a-u 3$ と $P C a-b 3$ は, 正負それぞれに対 して検討した

*2（）内は最大耐力時の最大あるいは最小到達軸力 $(\mathrm{kN})$ 
は横拘束の影響が考慮されないし，また，基礎部による柱脚部コンク リートの拘束効果も計算値に対して実験值を上昇させる要因となる。

文献 12),13)では，崎野らによる拘束コンクリート応力ーひずみ関 係の提案式を用い, 横拘束の効果に補正を加えて解析を行うことで実 験結果を適切に予測できるとしている。ACI のコンクリート応カブロ ックを利用すると,横拘束の効果を考虑したコンクリートのモデ化 を利用したときと比べて，中立軸位置が深くなり，曲げ耐力が小さく 評価されてしまう。

図 4 に ACI のコンクリート态カブロックと平面保持仮定を用いて 算定される曲け耐力に対する，本実験及び過去に行われた PCaPC 柱 部材に関する研究 14),15),16)より得られた曲げ耐力の実験値の比を軸力 比十王縮側プレストレスレベル（有効プレストレスカ/（柱断面積 $\mathrm{x}$ コンクリート圧縮強度)）に対して示す。柱断面で二段配筋となって いるので，圧縮側 2 本の PC 鋼材による有効プレストレスカのみを考 慮している。付着の有無に関係なく軸力比が大きくなるにしたがって 曲け耐力の比は大きくなる。同図には, Ang らによる提案式を破線で 示した。Ang らの提案式は実験結果とよく整合している。なお, 文献

表 5 付着の有無による最大耐力の比較

\begin{tabular}{|c||c|c|c|}
\hline 試験体 & 正載荷時 & 負載荷時 & 平均 \\
\hline \hline$P C a-u 1 / P C a-b 1$ & 0.95 & 0.95 & 0.95 \\
\hline$P C a-u 2 / P C a-b 2$ & 0.98 & 1.00 & 0.99 \\
\hline$u 1 / b 1$ & 0.86 & 0.97 & 0.91 \\
\hline$u 2 / b 2$ & 1.03 & 0.87 & 0.95 \\
\hline
\end{tabular}

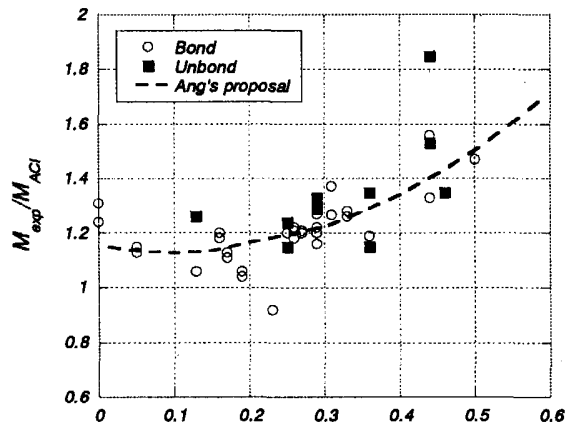

Axial load level + Prestress level (compression side)

図 4 平面保持仮定による曲げ耐力

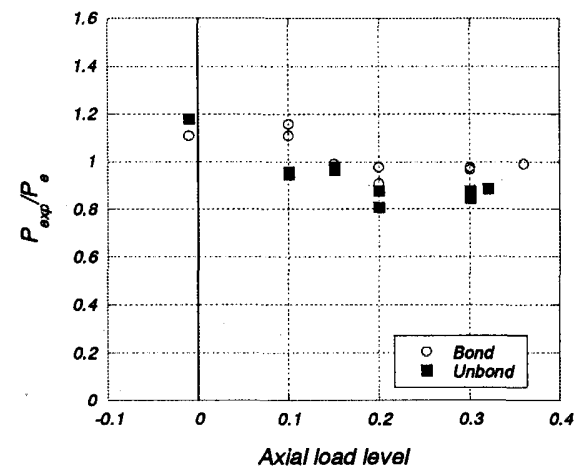

(a) カラナット

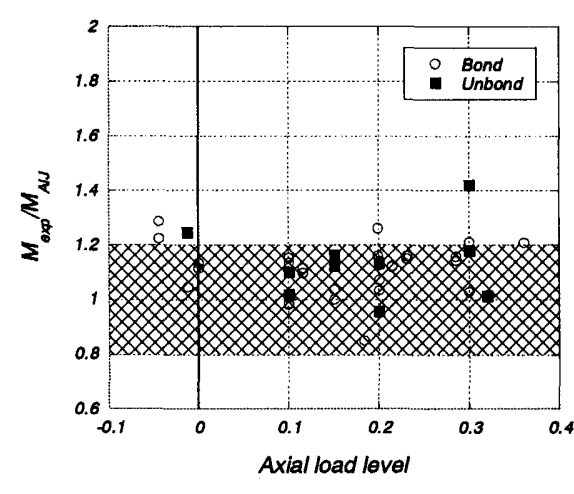

図 5 B 法による曲げ耐力

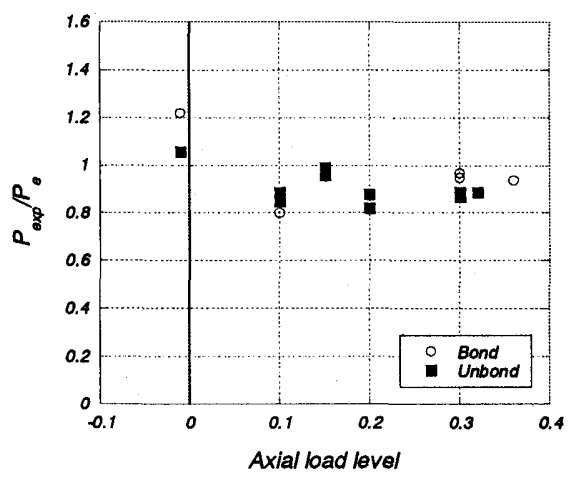

(b) ひずみゲージ

図 6 最大耐力時の PC 鋼材張力合計值

14)では導入プレストレスカに 0.85 を乗じて有効プレストレスカとし た。

また，付着のある試験体とない試験体の曲げ耐力を比較して表 6 に示す。正負曲け耐力の平均值で比較すると, 付着のない試験体は, 付着のある試験体に対して 91〜99\%の耐力となっている。軸力のな い梁部材の場合には, 鋼材の張力評価により曲げ耐力が決まることに なるが, 柱部材の場合には, 特に高軸力を受ける場合, 鋼材が弾性範 囲にあることと、コンクリートが大きな影響を持つようになることに より, 付着の有無による曲げ耐力の差は小さい。

次に, B 法に関する妥当性の検討を行う。本実験の試験体と併せて, 既往の研究 14),15),16ににおける曲け耐力の実験值と提案式より算出した 曲げ耐力の比を縦軸に, 軸力比を横軸にとり, 図 5 に示す。引張力を 受ける試験体，もしくは軸力比が 0.2 を超えるような試験体では, 耐 力を幾分か小さめに評価する傾向が見られるが, 全体的に実験結果と 非常によく整合している。

なお, $\mathrm{PC}$ 鋼材の圧縮側判定に用いる $x_{n}$ の第一次近似に関して, 梁 部材を対象とした学会式では PC鋼材降伏耐力を使用しているのに対 し, 本論文で示す柱部材を对象とした提案式では有効プレストレスカ を使用する理由を以下に示す。

実験において, 各試験体の最大耐力時にカラナット及びひずみゲ 一ジより計測された PC鋼材張力の合計值と有効プレストレスカの比 を図 6 に示す。図 6 に示す通り，実験における曲げ耐力時の PC 鋼材 張力合計值は, ほとんどが有効プレストレスカから減少している。こ れは,軸力の影響により柱自体の軸圧縮ひずみが增大するためである。 なお, PC 鋼材の降伏耐力は, 試験体により異 なるが, 有効プレストレスカの $1.38 \sim 1.60$ 倍 となっており，もし，梁部材と同様に， $x_{n}$ の 第一次近似に PC鋼材の降伏耐力を用いると, 実際の值よりかなり大きな PC 鋼材張力值を 用いることになる。PC 鋼材張力の過大評価は， コンクリート压縮合力を過大評価することに 慗がり， $x_{n}$ を実際より大きく評価し，PC 鋼材 が圧維側にあるか，引張側にあるかの判定に 大きな影響を及ぼす。また, 降伏耐力に対す る有効プレストレスが小さい場合には，その 誤差はさらに大きくなる。しかし，曲耐力 時の正確な PC 鋼材張力の合計值を算出する ことは煩雑であることや，図 6 に示す通り， 曲け耐力時の PC 鎆材張力合計值が有効プレ ストレスカからそれほど変動していないこと から,PC 銅材の圧縮側判定に用いる $x_{n}$ の第一 次近似に有効プレストレスカを用いることは 妥当であろう。

また，(5)式中の PC 鋼材張力の和 $\left(=\mathrm{a}_{\mathrm{p}} \sigma_{\mathrm{py}}+\Sigma \xi_{\mathrm{j}} \mathrm{P}_{\mathrm{ei}}\right)$ で与えられる $\mathrm{PC}$ 鋼材の最終 的な張力は, 実験で得られた曲け耐力時の PC 鋼材張力の合計値と，ほとんどの試験体にお いてほぼ同じ值となった。ただし，有効プレ 
ストレスカを含めた軸力比が 0.27 0.64 の変動軸力を受ける試験体 では，(5)式の值が実験值のほほ 140\%（軸力比 0.27 時）及び 60\%（軸 力比 0.64 時）.となった。これは, 軸力比が極端に小さい又は大きい 場合には, (2)式から求まる $\mathrm{x}_{\mathrm{n}}$ による PC 鋼材の圧維側判定において, 全ての PC 鋼材が引張側又は圧縮側と判定されるためである。

PC 規準に示される耐力算定式 ${ }^{17}$ の計算值之，本実験の付着ありの

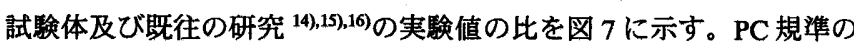
耐力算定式を用いる場合には，安全側として通常圧縮側の PC 鋼材は 無視されることが多い。ここでの耐力算定もこれにならい，圧縮側の PC 鋼材の効果を無視した。図 7 に示す通り，全体的に耐力を過小評 価しており，実験值と計算值の間にはかなりの開きがある。これは， 各既往の研究での試験体には压縮側にも PC鋼材や鉄筋が配置されて いるが，PC 規準式では圧維側の PC 鋼材や鉄筋を考虑していないた めである。また，PC 規準では軸力が大きい場合には適用できないと の記述があるものの，軸力レベルが高い試験体に限らず，低い試験体 についてもかなりの誤差が発生していることが図 7 から読み取れる。 これは，軸カレペルが低い武験体では圧縮側の PC 鋼材張力が大きく なるため，圧編側 PC 銅材を考慮しない影部が大きくなり，大幅に耐 力を過小評価したものと考えられる。

\section{4 曲げ耐力算定に影签を与える因子}

圧着柱の曲け耐力算定には以下の 3 つの要素が影䉒を与える：

(1) 引張側 PC 材張力の評価

（2）圧縮側 PC 銅材が圧縮筋として㑬くか，引張筋として張力を負担 するか

(3) 圧縮コンクリートの圧維合力評価

本実験での曲け耐力時の PC 鋼材ひずみは表 6 のようになる。付着 のある試験体では，柱脚部位圈での PC 銅棒に貼付したひずみゲージ から得られた值であり，付着のない試験体では，PC 鋼棒端部に取り 付けたロードセルにより得られた值を示している。ここで，

$\varepsilon_{\text {ptexp }}:$ 引張側 PC 鋼材の平均ひずみ（実験値）

$\varepsilon_{\text {pc.exp }}$ : 圧縮側 PC 鋼材の平均ひずみ（実験値）

$\varepsilon_{\text {ptana }}$ : 引張側 PC 鋼材の平均ひずみ（PC 鋼材に対しても平面保持を 仮定した解析値)

$\varepsilon_{\text {pcana }}$ 圧維側 PC 鎆材の平均ひずみ（PC鋼材に対しても平面保持を 仮定した解析值)

である。

表 6 には, ACI の応カブロッ クを使用し，平面保持を仮定 した場合の鋼材ひずみ（ $\varepsilon_{\text {ptana }}$ と $\left.\varepsilon_{\text {pc.ana }}\right)$ に対して, 実際の鋼 材ひずみ $\left(\varepsilon_{\text {phexp }}\right.$ と $\left.\varepsilon_{\text {pc.exp }}\right)$ が どの程度の割合になっている かを示している。表 7 には， 解析により得られる PC鋼材位 置でのコンクリートひずみ増 分 $\Delta \varepsilon_{\text {ana }}$ に対する，実験より 得られた PC銅材ひずみ増分 $\Delta$

$\varepsilon_{\text {exp }}$ の比, いわゆるひずみの適合倸数 $\mathrm{F}$ 值を示す。軸力比の変化に 伴って F 值が変化する傾向は見られない。表 7 の PCa-u2,u2 のよう に軸力比が大きい場合には, PC 鋼材位置におけるコンクリートひず み增分は 0 に近い值や負の値を示すことから， $\mathrm{F}$ 值の適切な評価は特 に困難なものとなる。また，逆対称曲げを受ける柱部材においては， PC 鋼材が柱脚で引張側であっても柱頭では圧縮側となるため, PC 鋼 材の伸びひずみは本論文で扱う片持ち部材のものと比べて小さくな ることに注意しなければならない。

実験では, 付着のある試験体の方が, 付着のない試験体に比べて, 引張側も圧縮側も小さな鋼材ひずみとなっている。しかしながら，曲 げ最大耐力は，ボンド試験体の方が大きい。

$\mathrm{ACI}$ のコンクリート応カブロックには, 横補強筋による拘束効果な 表 6 曲け耐力時 PC鋼材ひずみ

\begin{tabular}{|c|c|c|c|c|c|c|c|}
\hline & $\begin{array}{l}\text { loading } \\
\text { direction }\end{array}$ & $\begin{array}{l}\varepsilon_{p t} \\
e x p \\
(\%)\end{array}$ & $\begin{array}{l}\varepsilon_{p c} \\
\exp \\
(\%)\end{array}$ & $\begin{array}{l}\varepsilon_{p t} \\
\text { ana } \\
(\%)\end{array}$ & $\begin{array}{l}\varepsilon_{p c} \\
a n a \\
(\%)\end{array}$ & \multicolumn{2}{|c|}{$\varepsilon_{\text {exp }} / \varepsilon_{\text {ana }}$} \\
\hline \multirow{2}{*}{$P C a-u 1$} & $+\mathrm{ve}$ & 0.361 & 0.286 & 0.348 & 0.309 & 1.04 & 0.93 \\
\hline & -ve & 0.266 & 0.381 & 0.309 & 0.348 & 0.86 & 1.09 \\
\hline \multirow{2}{*}{$P C a-u 2$} & +ve & 0.334 & 0.256 & 0.333 & 0.305 & 1.00 & 0.84 \\
\hline & -ve & 0.256 & 0.316 & 0.305 & 0.333 & 0.84 & 0.95 \\
\hline \multirow{2}{*}{$P C a-b 1$} & +ve & 0.278 & 0.109 & 0.421 & 0.225 & 0.66 & 0.48 \\
\hline & -ve & 0.117 & 0.308 & 0.225 & 0.421 & 0.52 & 0.73 \\
\hline \multirow{2}{*}{$P C a-b 2$} & +ve & 0.207 & 0.035 & 0.346 & 0.190 & 0.60 & 0.18 \\
\hline & -ve & 0.048 & 0.226 & 0.190 & 0.346 & 0.25 & 0.65 \\
\hline \multirow{2}{*}{$u 1$} & +ve & 0.394 & 0.307 & 0.385 & 0.344 & 1.02 & 0.89 \\
\hline & -ve & 0.312 & 0.383 & 0.344 & 0.385 & 0.91 & 0.99 \\
\hline \multirow{2}{*}{$u 2$} & +ve & 0.366 & 0.288 & 0.379 & 0.346 & 0.97 & 0.83 \\
\hline & -ve & 0.279 & 0.326 & 0.346 & 0.379 & 0.81 & 0.86 \\
\hline \multirow{2}{*}{$b 1$} & +ve & 0.280 & 0.282 & 0.455 & 0.246 & 0.62 & 1.15 \\
\hline & -ve & 0.082 & 0.476 & 0.246 & 0.455 & 0.33 & 1.05 \\
\hline \multirow{2}{*}{$b 2$} & +ve & 0.466 & 0.206 & 0.421 & 0.252 & 1.11 & 0.82 \\
\hline & -ve & 0.255 & 0.416 & 0.252 & 0.421 & 1.01 & 0.99 \\
\hline
\end{tabular}

*PC 鋼材の $0.2 \%$ オフセット降伏応力に対応するひずみは, $0.727 \%$ **実験開始時（軸力載荷後）の有効プレストレスによる PC 鋼材ひ ずみは, PCa-u1: 0.332\%, PCa-u2: 0.336\%, PCa-b1: 0.341\%, PCa-b2: $0.336 \%, u 1: 0.366 \%, u 2: 0.373 \%, b 1: 0.350 \%, \quad b 2: 0.382 \%$

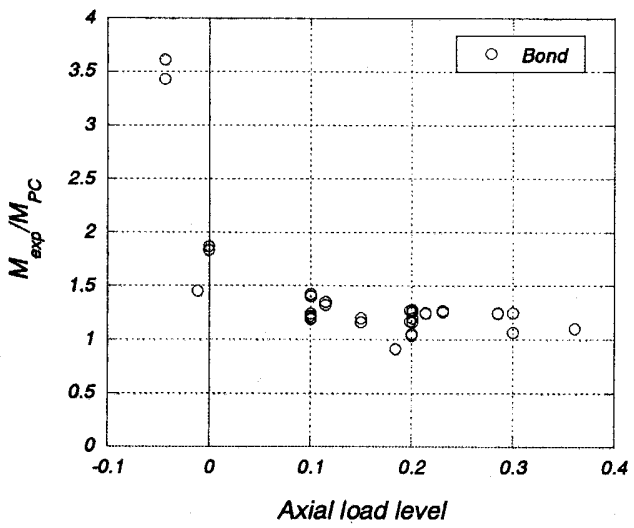

図 7 PC 規準式による曲げ耐力
表 7 引張側鋼材に対するひずみ適合倸数 $\mathrm{F}$ 值

\begin{tabular}{|c||c|c|c|c|}
\hline & $\begin{array}{c}\text { Loading } \\
\text { direction }\end{array}$ & $\begin{array}{c}\Delta \varepsilon_{\text {ana }} \\
(\%)\end{array}$ & $\begin{array}{c}\Delta \varepsilon_{\text {exp }} \\
(\%)\end{array}$ & $\mathrm{F}$ \\
\hline \hline \multirow{2}{*}{$P C a-u 1$} & $+\mathrm{ve}$ & 0.078 & 0.029 & 0.372 \\
\cline { 2 - 5 } & $-\mathrm{ve}$ & 0.078 & 0.049 & 0.629 \\
\hline \multirow{2}{*}{$P C a-u 2$} & $+\mathrm{ve}$ & -0.013 & -0.002 & 0.153 \\
\cline { 2 - 5 } & -ve & -0.013 & -0.020 & 1.530 \\
\hline \hline \multirow{2}{*}{$u 1$} & $+\mathrm{ve}$ & 0.093 & 0.028 & 0.302 \\
\cline { 2 - 5 } & -ve & 0.093 & 0.017 & 0.183 \\
\hline \multirow{2}{*}{$u 2$} & $+\mathrm{ve}$ & 0.028 & -0.007 & -0.248 \\
\cline { 2 - 5 } & $-\mathrm{ve}$ & 0.028 & -0.047 & -1.664 \\
\hline
\end{tabular}


どは入っておらず, コンクリート圧縮合力は安全側の值となる。した がって, 中立軸位置が大きめに評価され, 結果として, 曲げ耐力計算 值は小さくなる傾向がある。

\section{4. 圧着柱の曲げ耐力算定}

以上の結果から, 平面保持を仮定して ACI 応カブロックを用いて 算出された酎力を Ang の式で補正する方法, 及び文献 7)の式に軸力 を受ける柱部材に適用できるよう修正を加えた提案式の両方で, 耐力 を算定することが可能である。なお, Ang の式に使用する軸力比には， 軸力比十圧縮側 PC 鋼材のプレストレスレベルを使用する。ただし， 現状ではPC柱に対する実験データが少ないのでさらに多くの実験テ 一タによる検証が必要であろう。

\section{5. まとめ}

グラウトを施した PC圧着柱試験体とグラウトを行わなかった試験 体に対する載荷実験結果より,その曲け耐力に関して以下のような結 論が得られた。

（1）実験で得られた付着のない試験体の曲げ耐力は, 正負載荷時を 平均すると，付着のある試験体の，91〜99\%となった。

(2) '平面保持を仮定して得られた, 付着のある試験体の曲げ耐力に 対して, 実験值は 6〜56\%大きくなった。また, 付着のない試 験体の曲け耐力は，鋼材の変形適合係数 $\mathrm{F}$ 值を 0.2 として得ら れた計算值より 15〜85\%大きくなった。また, 曲け耐力時の PC 鋼材ひずみについて見てみると，平面保持を仮定した解析から 得られる値に対して 18〜115\%となった。ただし，付着のある 試験体に対して得られた小さな值は, ひずみゲージから得られ た值であり，その值の信頼性に疑問がある。

(3) 付着ありなしに関係なく, 平面保持を仮定した解析より得られ た曲げ耐力を, Ang らが提案する曲げ耐力拡大係数を用いて修 正すると実験結果の曲げ耐力に近い值を得ることができる。た だし，この際，原式の軸力比を，軸力比十圧縮側鋼材のプレス トレスレベルで置き換える。これは，柱の曲け耐力時に鋼材の ひずみ増分が小さく，降伏ひずみにまで達していないため，付 着の有無による鋼材張力增分の差が顕著ではなかったためと 考えられる。また，柱軸力が大きく設定されており，PC 鋼材 よりもコンクリートの影響が大きいため, 通常の RC 柱に対し て誘導された Ang らの式が適用できたものと考えられる。

（4）文献 7),8)で示されている終局曲け強度算定式を, 軸力を受ける 柱部材にも適用できるよう修正し, 提案式を示した。ほとんど の試験体において $20 \%$ の精度で耐力を予測することができた。 ただし, 限られた軸力の範囲, プレストレスレベルの範囲の実験デ 一タしかないので, 今後さらに実験デー夕を収集すべきである。また, 鋼材とグラウト間の付着一すべり関係をモデル化した数值解析によ る検討も行っており，抵抗機構を考慮の上，別の機会に発表する予定 である。また，変形能力に関する評価も検討中である。

\section{謝辞}

本研究を進めるにあたり，高周波熱鍊株式会社より PC 鋼材を御提供
頂いた。ここに謝意を示す。

参考文献

1) 坂静雄, 六車熙 : 付着のない PC 梁の曲げ破壊耐力, 日本建築学会論文報 告集, pp.641 644, 1958.10

2) 竹本靖 : アンボンド PRC 部材の曲げ終局時テンドン応力について，大林 組技術研究所報, No.28，1984.2

3) Antoine E. Naaman, Ned Burns, Catherine French, William L. Gamble, and Alan H. Mattock: Stresses in Unbonded Prestressing Tendons at Ultimate: Recommendation, ACI Structural Journal, Vol.99, No.4, pp.518-529, 2002.7-8

4) M. Nishiyama, H. Muguruma and F. Watanabe: Hysteretic Restoring Force Characteristics of Unbonded Prestressed Concrete Structure under Earthquake Loads, Bulletin of the New Zealand National Society for Earthquake Engineering Vol.22, No.2, pp.112-121, 1989.6

5) 上田正生, 山本俊彦, 井手斉 : アンボンド PC スラフの有限要素解析，コ ンクリート工学年次論文集，Vol.11，No.2，pp.411-416，1989.6

6) 六車熙，渡邊史夫，西山峰広 : アンボンド PC 部材の曲け終局耐力に関す る研究，ブレストレストコンクリート vol.26, pp.10-16, 1984.1

7) 日本建築学会 : 保有耐力と変形性能(1990)プレストレストコンクリート， pp.508-509, 1990

8）岸本一蔵，鈴木計夫，中塚佶 : コンクリート曲げ部材断面の曲げ終局強 度と曲げ変形性能に関する解析的考察，日本建築学会近轹支部研究報告 集, pp.429-432, 1989.5

9) 芹澤好徳, 前田博司, 西山峰広 : アンボンド圧着接合柱の力学性状に関 する研究，日本建策学会大会学術講演梗概集 (東海)，C-2, pp.1015-1018， 2003.9

10) 稲田剛知, 西山峰広 : アンボンド PC 压着柱の耐震性能, 第 13 回プレス トレストコンクリートの発展に関するシンボジウム論文集, pp.79-84, 2004.10

11) Ang Beng Ghee, M. J. N. Priestley and T. Paulay: Seismic Shear Strength of Circular Reinforced Concrete Columns, ACI Structural Journal, Vol.86, No.1, pp.45-59, 1989.1-2.

12）前田博司，岸本一蔵，西山峰広：PC 鎆材の付着すべりを考慮したプレキ ヤスト PC 部材の履歴挙動解析法,コンクリート工学年次論文報告集，

Vol.26, No.2, pp.709-714, 2004.6

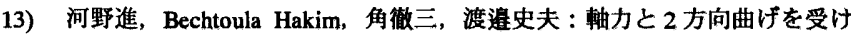
る実大 RC 柱の損傷評価，コンクリート工学年次論文集，Vol.24，No.2, pp.235-240, 2002.6

14）浜田公也，大迫一德，傅金華，林三雄：100 $/ \mathrm{mm}^{2}$ 級の高強度コンクリー 卜を用いた PCaPC 柱の実験研究, 日本建築学会学術講演梗概集 (東海), pp.1025-1028, 2003.9

15）浜戸昇他：PCaPC 高層建物における PC 柱の実験的研究，日本建築学会 学術講演梗概集 (九州)，pp.1003-1006，1998.9

16）尹元奎, 浜原正行, 本岡順二郎 : プレキャスト・プレストレストコンク リート柱の復元力特性に関する実験的研究，日本建築学会構造系論文集， 第 480 号，pp.151-160，1996.2

17）日本建築学会 : プレストレストコンクリート設計施工規淮・同解説, Pp.182-183, 1987 